\title{
Yield and grape must composition in 'Cabernet Sauvignon' grape vine subjected to potassium fertilization in high altitude soil
}

\author{
Djalma Eugênio Schmitt ${ }^{1} \oplus$, Jucinei José Comin²®, Paula Beatriz Sete ${ }^{1}{ }^{\oplus}$, \\ Talita Trapp ${ }^{2} \odot$, Vitor Gabriel Ambrosini ${ }^{3}$, Gustavo Brunetto ${ }^{4} \mathbb{C}$

\footnotetext{
${ }^{1}$ Universidade Federal de Santa Catarina, Curitibanos, SC, Brasil. E-mail: djalma.schmitt@gmail.com; paulasete@gmail.com

2 Universidade Federal de Santa Catarina, Centro de Ciências Agrárias, Florianópolis, SC, Brasil. E-mail: j.comin@ufsc.br; talipptrali@yahoo.com.br

${ }^{3}$ Universidade Federal do Rio Grande do Sul, Porto Alegre, RS, Brasil. E-mail: vgambrosini@gmail.com

${ }_{4}^{4}$ Universidade Federal de Santa Maria, Santa Maria, RS, Brasil. E-mail: brunettogustavo@gmail.com
}

ABSTRACT: Potassium (K) increase in the soil can affect grape must yield and quality; and consequently, the quality of wine; however, studies in this field approaching altitude soil in Southern Brazil (used for viniculture) are scarce. The aim of the present study is to evaluate yield, critical K level in the leaves and their association with grape must composition in 'Cabernet Sauvignon' vines subjected to K application in high altitude soil in Southern Brazil. The experiment was performed in a 'Cabernet Sauvignon' vineyard subjected to the application of different $\mathrm{K}$ doses $\left(0,30\right.$ and $60 \mathrm{~kg} \mathrm{~K}_{2} \mathrm{O}$ ha-1) in three seasons. Potassium (K) availability in soil and leaves, as well as total soluble solids (TSS), $\mathrm{pH}$, total titratable acidity (TA) content in grape must were evaluated. Potassium fertilizer applications increased $\mathrm{K}$ availability in the soil, but its concentration only increased in leaves collected at full bloom in the 2013/2014 season. Potassium applications in the soil did not affect yield, but $K$ concentration increase in the leaves led to increased TSS and pH values in grape must, as well as to TA and tartaric acid decrease, a factor that can impair the quality of wine.

Key words: available K; leaf analysis; leaf K; Vitis vinifera L.

\section{Produtividade e composição do mosto em videira 'Cabernet Sauvignon' submetidas à adubação potássica em solo de elevada altitude}

RESUMO: $\mathrm{O}$ incremento de $\mathrm{K}$ no solo pode afetar a produtividade e qualidade do mosto, por consequência, do vinho. Mas, estudos desta natureza são escassos em solos de altitude do Sul do Brasil, que são incorporados a viticultura. 0 estudo objetivou avaliar a produtividade, nível crítico de $\mathrm{K}$ em folhas e a relação com a composição do mosto em uva 'Cabernet Sauvignon' submetidas à aplicação de K em solo de altitude no Sul do Brasil. $\mathrm{O}$ experimento foi realizado em vinhedo da 'Cabernet Sauvignon', cujas plantas foram submetidas a aplicações de doses de $\mathrm{K}\left(0,30\right.$ e $60 \mathrm{~kg} \mathrm{~K}_{2} \mathrm{O}$ ha-1) durante três safras. Foram avaliados os teores de $\mathrm{K}$ disponivel no solo e nas folhas, além dos teores de sólidos solúveis totais (SST), pH do mosto, acidez titulável (AT) e quantidade de ácido tartárico no mosto. As aplicações de fertilizantes potássicos aumentaram os teores de $\mathrm{K}$ disponíveis no solo, mas somente incrementaram a concentração de $\mathrm{K}$ nas folhas coletadas no pleno florescimento na safra 2013/2014. As aplicações de K no solo não afetaram a produtividade, mas, o incremento da concentração de $\mathrm{K}$ em folhas promoveu aumento dos valores de SST e no pH do mosto, e diminuição dos valores de AT e ácido tartárico o que pode prejudicar a qualidade do vinho.

Palavras-chave: $\mathrm{K}$ disponível; análise foliar; $\mathrm{K}$ folha; Vitis vinifera $\mathrm{L}$. 


\section{Introduction}

Altitude soils in Southern Brazil, including the ones cultivated with vines, are often acidic and present high organic matter contents and variation in potassium (K) availability level (Almeida et al., 2018). The highest natural exchangeable $\mathrm{K}$ contents are observed in soil with potassium from other sources such as minerals (Teske et al., 2013) and with high cation exchange capacity (CEC), which accounts for exchangeable $\mathrm{K}$ absorption - there must be $\mathrm{K}$ balance in the solution absorbed by plants (Poonpakdee et al., 2018), including vines. However, grapes from producing 'Cabernet Sauvignon' vineyards - including those grown in high altitude soils in Santa Catarina State (SC) - are destined to fine wine production. Potassium absorption is often observed because of $\mathrm{K}$ export by grape bunches and of the depletion of native exchangeable $\mathrm{K}$ content from soil or even of $\mathrm{K}$ derived from fertilization, such as pre-planting, before vineyard. Therefore, it is necessary fertilizing the soil for potassium maintenance (or production) during vines' productive period.

Fertilization with Potassium is necessary and $\mathrm{K}$ maintenance doses must be in compliance with the exchangeable $\mathrm{K}$ content in soil (extracted by Mehlich-1), as well as with total $\mathrm{K}$ concentration in leaves and yield expectations (CQFS-RS/ SC, 2016). However, estimates about soil exchangeable $K$ are not always related to yield parameters or to grape yield in producing vineyards, since vines' root system exploits a larger soil volume than the herein sampled soil volume (Tramontini et al, 2013; CQFS-RS / SC, 2016) and has internal nutrient reserves, including $\mathrm{K}$ (Pradubsuk \& Davenport, 2010). Therefore, estimates of nutrient concentrations, such as estimates of $\mathrm{K}$ content in leaves, (assessed at full bloom or at berries-color-change time) can be closely related to vineyards' yield parameters, as well as to grape must oenological parameters such as (TST), pH, total titratable acidity (ATT), malic acid, among other parameters (Ciotta et al., 2016; Messiga et al., 2016) that can influence the quality of the wine (Walker \& Blackmore, 2012). It is likely estimating $\mathrm{K}$ critical level in leaves (collected at full bloom) to assess oenological quality parameters in grape must, since these parameters can also apply to other wine types. Based on such estimates, producers could predict the quality of the wine and make better decisions about its storage and the target public for each wine type.

The predictability of $K$ concentration in the leaves can be used as tool to estimate oenological quality parameters in grape must - this procedure is justified by the normal $\mathrm{K}$ application in the soil. Plant growth, mainly in soil presenting medium or clayey texture and high organic matter content does not affect yield (Sipiora et al., 2005; Ciotta et al., 2016). However, $\mathrm{K}$ accounts for $75 \%$ of the cation observed in most berries (Rogiers et al., 2017); thus, high $\mathrm{K}$ concentrations in vines are likely diagnosed through leaf analysis, since they are related to $\mathrm{K}$ concentration in berries. In this case, higher $\mathrm{pH}$ and ATT in grape must result from $\mathrm{K}$ and from the formation of organic acid complex such as K bi-tartrate, which can precipitate in must (Davies et al., 2006). This process can have negative effect on the color (Walker \& Blackmore, 2012), aroma and stability of wine (Davies et al., 2006); besides, higher $\mathrm{pH}$ in grape must is associated with fermentation stability (Conde et al., 2007). However, knowledge on must from grape grown in altitude soil - which often presents clayey texture and high organic matter content - remains incipient. This soil type is associated with higher natural CEC values recorded in experiments conducted in more than one season, as the present one.

The aim of the present study was to evaluate the yield, critical $\mathrm{K}$ level in the leaves and their association with the composition of grape must from 'Cabernet Sauvignon' vines subjected to $\mathrm{K}$ application in high altitude soil in Southern Brazil.

\section{Materials and Methods}

The study was conducted in a vineyard located in Água Doce, Midwestern Santa Catarina State (SC), Southern Brazil (latitude 260 42 '10 “, longitude 510 43' 49”). Climate in the region is classified as temperate oceanic ( $\mathrm{Cfb})$ with mild summers, according to Köppen-Geiger's classification. The number of accumulated chilling hours $\left(\leq 7.2^{\circ} \mathrm{C}\right)$ ranges from 642 to 778 hours per year. Mean air temperature and rainfall are shown in Figure 1. The soil in the vineyard was classified as Cambissolo Húmico (Santos et al., 2013) or Typic Humicryept (Soil Survey Staff, 2010) or Humic Cambisol (FAO et al., 1998).

'Cabernet Sauvignon' vines (Vitis vinifera L.) were grafted onto 'Paulsen 1103' rootstock (Vitis berlandieri $\times$ Vitis rupestris). The vines were trained in the vertical shoot position (VSP) system and spaced $2.9 \mathrm{~m} \times 1.5 \mathrm{~m}$ from each other, thus totaling 2,299 plants per hectare. Soil chemical features in the 0-20 cm layer before experiment installation were $445 \mathrm{~g} \mathrm{~kg}^{-1}$ clay (pipette method) and $63 \mathrm{~g} \mathrm{~kg}^{-1}$ organic matter (WalkleyBlack method); $\mathrm{pH}$ in water 6.1 (ratio 1: 1); 6.9 and $4.7 \mathrm{cmol}$ $\mathrm{kg}^{-1}$ of $\mathrm{Ca}$ and $\mathrm{Mg}$, respectively (extractor $\mathrm{KCl} 1 \mathrm{~mol} \mathrm{~L}^{-1}$ ); 7.2 and $260 \mathrm{mg} \mathrm{kg}^{-1}$ of available $\mathrm{P}$ and $\mathrm{K}$ (Mehlich 1 extractor) (Tedesco

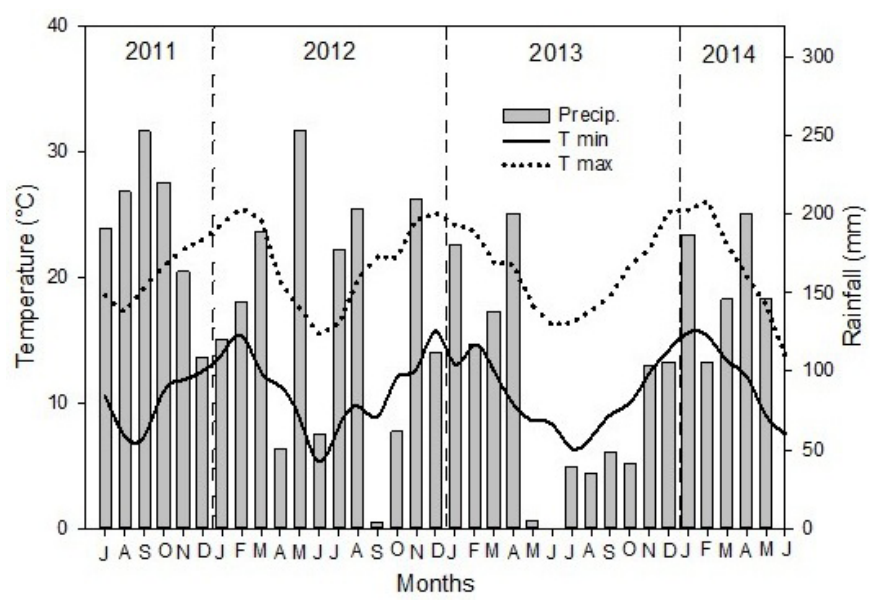

Figure 1. Rainfall ( $\mathrm{mm}$ ), maximum mean temperature ( $T$ max) and minimum mean temperature ( $\mathrm{T} \mathrm{min}$ ) recorded from July 2011 to June 2014 in Água Doce - SC (Epagri, 2019). 
et al., 1995); 13.1 and $17.5 \mathrm{cmol}_{\mathrm{c}} \mathrm{kg}^{-1}$ of $\mathrm{CEC}_{\text {effective }}$ and $\mathrm{CEC}_{\mathrm{pH7.0}}$ respectively. Vines were subjected to applications of 0,30 and $60 \mathrm{~kg} \mathrm{~K}_{2} \mathrm{O}$ ha $^{-1}$ year ${ }^{-1}$ from the 2011/2012 to 2013/2014 season - applications were performed at the beginning of bud burst. Potassium chloride $\left(\mathrm{KCl}, 60 \% \mathrm{~K}_{2} \mathrm{O}\right)$ applied on crown projection area and on soil surface (without incorporation) was the $\mathrm{K}$ source. The research followed the randomized blocks experimental design with four replications. Each plot comprised six vines, but only the three central plants were evaluated.

Interline vegetation mostly encompassed white clover (Trifolium repens), ryegrass (Lolium multiflorum) and Festuca (Festuca arundinacea). Vegetation was grazed to $10 \mathrm{~cm}$ tall every 50 days; plant waste was deposited on soil surface.

Soil samples were collected in the $0-20 \mathrm{~cm}$ layer after the berry-color-change time, in all assessed seasons. Soil was air dried, ground, sieved in 2-mm mesh and subjected to $\mathrm{K}$ availability analysis (Mehlich 1 extractor) through lame photometry. In total, 10 mature leaves per plant were collected in the mid-third of the branch of the year at full flowering and berry-color-change time. The leaves were dried in forced air oven at $65^{\circ} \mathrm{C}$ until constant weight was reached; next, they were ground and subjected to sulfur digestion (Tedesco et al., 1995). Potassium concentration in the extract was determined through flame photometry.

The number of clusters per vine was counted at harvest; all clusters were collected and weighed to determine yield. A sample comprising five clusters per vine was evaluated to assess mass $(\mathrm{g})$, length $(\mathrm{cm})$, and width $(\mathrm{cm})$. Three samples, with 50 berries each, were randomly collected from different clusters, at different positions. Berries were crushed for grape extraction; grapes were subjected to chemical analysis in order to determine soluble solids content (oBrix) in RTD-45 digital refractometer adjusted to temperature compensation (Instrutherm, São Paulo, Brazil); titratable acidity through titration $(0.1 \mathrm{~N} \mathrm{NaOH})$ in $1 \%$ phenolphthalein (meq $\mathrm{L}^{-1}$ ); $\mathrm{pH}$ measured in AD1030 pH meter (ADWA, Szeged, Hungary); and tartaric acid calculated in LC-10A high-performance liquid chromatography equipment (Shimadzu, Kyoto, Japan).

Results were subjected to analysis of variance; regression equations were adjusted through linear model testing through $\mathrm{F}$ test when effects were significant - results showing significance level lower than $5 \%(p<0.05)$ were chosen. Regressions among $\mathrm{K}$ concentration in the leaves, flowering yield, total soluble solids, grape must $\mathrm{pH}$, total acidity and tartaric acid in grape must were also performed. Relative yield $(\mathrm{rr})$ was calculated through equation $\mathrm{rr}=(\mathrm{rt} / \mathrm{rm}) * 100$; wherein, $r$ is treatment yield and $r m$ is maximum yield. The $r r$ results were related to $\mathrm{K}$ content in the leaves at full flowering in complete leaves - it was calculated to find the sufficiency level referring to $90 \%$ rr. Mathematical adjustment between variables was performed by applying the Mitscherlich model $\hat{y}=a(1-b x)$; where in, $\hat{y}$ represents $r r$, $a$ and $b$ are constants, and $x$ is the nutrient content in the leaves.

\section{Results and Discussion}

Potassium availability in the $0-20 \mathrm{~cm}$ soil layer increased after the application of $\mathrm{K}$ fertilizer at the tested doses (Table 1); the recorded results were 3.6, 5.6 and $3.1 \mathrm{mg} \mathrm{K} \mathrm{kg}$ of $\mathrm{K}_{2} \mathrm{O}$ applied in the $2011 / 2012,2012 / 2013$ and 2013/2014 seasons, respectively. This result derives from $\mathrm{K}$ fertilizer solubilization in the soil, which increases $K$ forms and the amount of $K$ solution available in the soil (exchangeable), estimated in Mehlich-1 extractor (Poonpakdee et al., 2018). The K contents in all treatments and seasons were very high (> $240 \mathrm{mg} \mathrm{K}$ $\mathrm{kg}$, for soils with $\mathrm{CEC}_{\mathrm{pH}, 0} 15.1$ to $30.0 \mathrm{cmol}_{\mathrm{c}} \mathrm{kg}$ ) (CQFS-RS/ SC, 2016), except for the control soil, in 2013/2014 season, which recorded high $\mathrm{K}$ content (121-240 mg of $\mathrm{K} \mathrm{kg}$, for soils with $\mathrm{CEC}_{\mathrm{pH7}, 0} 15.1$ to $30.0 \mathrm{cmol}_{\mathrm{c}} \mathrm{kg}$ ) (CQFS-RS/SC, 2016). Very high or high $\mathrm{K}$ availability (exchangeable) levels in vineyard soils, without nutrient application, likely resulted from the weathering of minerals such as micas and feldspars that end up working as $\mathrm{K}$ source (Melo et al., 2004). These minerals can be found in acidic volcanic rocks composing the soil in the assessed region (Dortzbach et al., 2016). In addition, these forms of $K$ (native to the soil), mainly those available in the solution, can be cyclized by native or implanted vegetation (Pérez-Álvarez et al., 2015; Oliveira et al., 2016) such as cover crop species found in vineyards - this process reduces the availability of $\mathrm{K}$ forms in the soil over time (Oliveira et al., 2016). On the other hand, part of $K$ available in the control soil and in treatments, in the assessed seasons, possibly derived from pre-planting fertilization, which was carried out before vineyard installation (Schmitt et al., 2014; Dalbó et al., 2015; Ciotta et al., 2016) - this procedure is natural in experiments ran in orchards or vineyards installed during crop production (Dalbó et al., 2015; Ciotta et al., 2016).

However, in the 2012/2013 season, K levels in the soil increased due to the application of $K$ doses (Table 1 ) but, in the 2013/2014 season, K availability levels decreased both in the control soil and in soils subjected to two $\mathrm{K}$ doses. This outcome can be related to higher $\mathrm{K}$ export by grape bunches, since there was greater grape yield in this season than in the $2012 / 2013$ one. This outcome can be explained by the fact that approximately $70 \%$ of $\mathrm{K}$ absorbed from the soil could have been allocated to bunches (Pradubsuk \& Davenport, 2010) and approximately $9 \mathrm{~kg}$ of $\mathrm{K}_{2} \mathrm{O}$ could have been exported per ton of grapes (Ganeshamurthy et al., 2011). Based on these results, grape yield expectations should continue to be used as auxiliary prediction criterion to define the $K$ dose needed by the grapevine, as already recommended by CQFS-RS/SC (2016). Potassium fertilizers can be applied even in soil recording intermediate and high $\mathrm{K}$ content, since the depletion of $\mathrm{K}$ forms available is fast, mainly in years of higher grape yield (Boonterm et al., 2013). Assumingly, the behavior observed in altitude Humic Cambissol soil in Midwestern Santa Catarina State has been incorporated to grapevine cultivation, but it may not have non-exchangeable $K$ reserves capable of buffering exchangeable $\mathrm{K}$, since there was approximate decrease by $100 \mathrm{mg} \mathrm{K} \mathrm{kg}^{-1}$ in the soil. The observed decrease was most likely caused by grape export, since soil relief was 
Table 1. Exchangeable $\mathrm{K}$ content in soil and total $\mathrm{K}$ content in the leaves at two collection times, number of bunches per plant, bunches mean mass, yield, bunches length and mean width of 'Cabernet Sauvignon' grapevines subjected to the application of increasing $\mathrm{K}_{2} \mathrm{O}$ doses in the soil.

\begin{tabular}{|c|c|c|c|c|c|c|}
\hline \multirow{2}{*}{ Variable } & \multicolumn{3}{|c|}{$\mathrm{K}_{2} \mathrm{O}$ dose $\left(\mathrm{kg} \mathrm{ha}^{-1}\right)$} & \multirow{2}{*}{ Equation } & \multirow{2}{*}{$\mathbf{R}^{2}$} & \multirow{2}{*}{ CV (\%) } \\
\hline & 0 & 30 & 60 & & & \\
\hline \multicolumn{7}{|c|}{$2011 / 2012$ season } \\
\hline Exchangeable $\mathrm{K}$ in the soil - after grape harvest $\left(\mathrm{mg} \mathrm{kg}^{-1}\right)$ & 233.4 & 277.4 & 448.8 & $y=212.2+3.59 x$ & $0.90 * *$ & 17.5 \\
\hline Total $\mathrm{K}$ in the leaves - flowering $\left(\mathrm{g} \mathrm{kg}^{-1}\right)$ & 13.6 & 14.1 & 14.6 & - & ns & 5.2 \\
\hline Total $\mathrm{K}$ in the leaves - berries-color-change season $\left(\mathrm{g} \mathrm{kg}^{-1}\right.$ ) & - & - & - & - & - & - \\
\hline Number of bunches per vine & 16 & 13 & 15 & - & ns & 17.2 \\
\hline Mean bunch mass (g) & 239 & 202 & 214 & - & ns & 9.7 \\
\hline Mean bunch length $(\mathrm{cm})$ & 12.9 & 12.8 & 12.0 & - & ns & 9.6 \\
\hline Mean bunch width $(\mathrm{cm})$ & 4.6 & 4.6 & 4.6 & - & ns & 5.3 \\
\hline Yield (Mg ha-1) & 8.5 & 6.1 & 7.1 & - & ns & 14.4 \\
\hline \multicolumn{7}{|c|}{$2012 / 2013$ season } \\
\hline Exchangeable $\mathrm{K}$ in the soil - after grape harvest $\left(\mathrm{mg} \mathrm{kg}^{-1}\right)$ & 205.3 & 307.5 & 540.7 & $y=183.2+5.60 x$ & $0.95^{* *}$ & 16.0 \\
\hline Total $\mathrm{K}$ in the leaves - flowering $\left(\mathrm{g} \mathrm{kg}^{-1}\right)$ & 10.9 & 10.6 & 12.1 & - & ns & 9.5 \\
\hline Total $\mathrm{K}$ in the leaves - berries-color-change season $\left(\mathrm{g} \mathrm{kg}^{-1}\right.$ ) & 20.2 & 20.6 & 23.5 & - & ns & 19.5 \\
\hline Number of bunches per vine & 12 & 11 & 12 & - & ns & 13.4 \\
\hline Mean bunch mass (g) & 69 & 62 & 62 & - & ns & 29.0 \\
\hline Mean bunch length $(\mathrm{cm})$ & 11.2 & 11.4 & 11.6 & - & ns & 8.7 \\
\hline Mean bunch width (cm) & 5.2 & 4.8 & 5.5 & - & ns & 10.2 \\
\hline Yield (Mg ha-1) & 1.8 & 1.5 & 1.8 & - & ns & 29.3 \\
\hline \multicolumn{7}{|c|}{$2013 / 2014$ season } \\
\hline Exchangeable $\mathrm{K}$ in the soil - after grape harvest (mg kg-1) & 143.1 & 213.0 & 330.1 & $y=135.1+3.13 x$ & $0.98 * *$ & 23.2 \\
\hline Total $\mathrm{K}$ in the leaves - flowering $\left(\mathrm{g} \mathrm{kg}^{-1}\right)$ & 21.8 & 18.4 & 20.6 & - & ns & 6.8 \\
\hline Total $\mathrm{K}$ in the leaves - berries-color-change season $\left(\mathrm{g} \mathrm{kg}^{-1}\right.$ ) & 14.8 & 17.9 & 19.5 & $y=15.09+0.077 x$ & $0.97 * *$ & 7.3 \\
\hline Number of bunches per vine & 20 & 22 & 25 & - & ns & 12.9 \\
\hline Mean bunch mass (g) & 115 & 124 & 132 & - & ns & 10.8 \\
\hline Mean bunch length $(\mathrm{cm})$ & 13.7 & 12.2 & 14.4 & - & ns & 10.7 \\
\hline Mean bunch width $(\mathrm{cm})$ & 5.8 & 5.6 & 6.5 & - & ns & 15.7 \\
\hline Yield (Mg ha-1) & 5.3 & 6.3 & 7.6 & - & ns & 22.7 \\
\hline
\end{tabular}

ns = not significant; ${ }^{* *}=$ significant, $\mathrm{p}<0.05 ;^{* * *}=$ significant, $\mathrm{p}<0.01 ; \mathrm{CV}=$ coefficient of variation.

flat and reduced surface runoff and debris transfer from soil cover species; moreover, pruned branches remained on the soil in the vineyards.

Potassium concentration in the leaves increased due to $\mathrm{K}$ dose when leaves were collected in the berries-color-change time in the 2013/2014 season (Table 1 ). Total increment of 0.08 $\mathrm{g} \mathrm{K}$ was observed for each $\mathrm{Kg}$ of $\mathrm{K}_{2} \mathrm{O}$ applied to the soil. There was no $\mathrm{K}$ concentration increase in leaves at leaf collection and full bloom. Potassium concentrations in leaves collected at leaf-color-change time in all seasons were normal $\left(8-16 \mathrm{~g} \mathrm{~kg}^{-1}\right)$ or excessive (above $16 \mathrm{~g} \mathrm{~kg}^{-1}$ ) (CQFS-RS/SC, 2016). Potassium concentrations in leaves collected at flowering time in vines that were not subjected to $\mathrm{K}$ application or to applications of two $\mathrm{K}$ doses in 2013/2014 season were approximately twice as higher as those observed in the previous season. This outcome is likely related to the higher absorption of $\mathrm{K}$ in the soil by vines, which reinforces the depletion of the available levels in the soil, since higher grape yield and, consequently, greater K export were observed in 2013/2014 (Ciotta et al., 2016). Based on this result, flowering must be the proper leaf collection stage to diagnose nutritional status in vines (Ciotta et al., 2016). However, it is necessary defining the critical $\mathrm{K}$ levels in the leaves based on quantitative parameters such as yield, or on qualitative ones such as grape must or wine oenological parameters.
Yield and its components (number of bunches per vine, mean bunch mass, yield, mean bunch length and bunch width) were not affected by the tested $\mathrm{K}$ doses (Table 1 ). However, yield results observed in the three evaluated seasons showed increase in this variable after $\mathrm{K}$ concentration increased in leaves collected at flowering (Figure 2A; Figure 2B). Yield increased by $0.36 \mathrm{Mg} \mathrm{ha}{ }^{-1}$ of grape, on average, for each increase in $\mathrm{K}$ concentration units in leaves at flowering. There was no yield increase at berries-color-change time related to $K$ content in the leaves and also between soil content and productivity (data not shown). Lack of association between yield and $\mathrm{K}$ content in the leaves may have resulted from vine roots' ability to absorb $\mathrm{K}$ forms available in deeper soil layers - 30 and $90 \mathrm{~cm}$ (Sipiora et al., 2005), rather than only in the $0-20 \mathrm{~cm}$ layer. Soil microorganisms and plant roots may have strategies such as $\mathrm{H}^{+}$or organic acids release to stimulate the solubilization of minerals that have $\mathrm{K}$ in their composition this process has increased the availability of $K$ forms in the soil (Sharma et al., 2016). The closer association between $\mathrm{K}$ concentration in the leaves in the assessed seasons and yield may have resulted from internal $\mathrm{K}$ reserves in perennial organs such as roots - decrease was observed in years recording higher grape yield and, consequently, greater $\mathrm{K}$ export by bunches (Pradubsuk \& Davenport, 2010; Ganeshamurthy et al., 2011). Thus, $K$ concentration gradient forms inside 

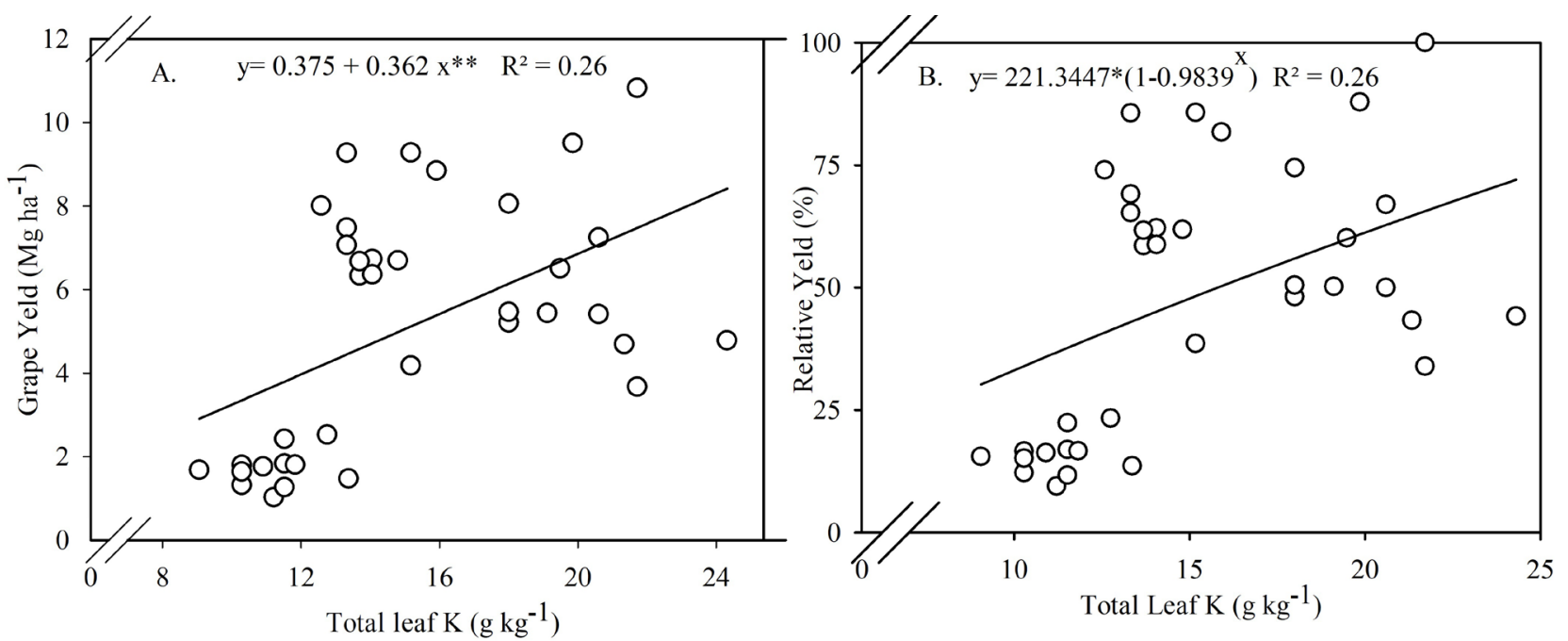

Figure 2. Linear regression between total K in leaves at flowering and the yield (A.) and relative yield (B.) of 'Cabernet Sauvignon' grapes subjected to the application of $\mathrm{K}_{2} \mathrm{O}$ doses.

plants (more $\mathrm{K}$ was observed in plants subjected to nutrient addition and lesser $\mathrm{K}$ was observed in plants recording lower $\mathrm{K}$ application history); it can be diagnosed through leaf analysis, according to which, vines presenting smaller $\mathrm{K}$ reserves may produce smaller amounts of grapes likely because of issues related to photosynthesis, mainly to functions related to water in plants, such as growth process, cell maintenance and turgor, and water transport via phloem (Liesche, 2016; Rogiers et al., 2017).

Applications of $\mathrm{K}$ doses did not affect grape must oenological parameters such as SST, pH, ATT and tartaric acid (Table 2). However, increased $\mathrm{K}$ concentration in leaves collected at flowering led to increased SST and $\mathrm{pH}$ values (Figure 3A; Figure 3B) and to decreased ATT and tartaric acid values in grape must (Figure 3C; Figure 3D). Increased SST values in grape must resulted from increased production of sugars; these values can contribute to proper grape must fermentation (Conde et al., 2007). On the other hand, increased pH values and decreased values of ATT and acids, such as the tartaric acid, resulted from complex formations - including organic acids and $\mathrm{K}$ - to form $\mathrm{K}$ bi-tartrate, which has negative effects on wine stability since it shortens wine storage time (a fact not always desirable) (Davies et al., 2006). Titratable acidity recorded high values and it reflected the concentrations of free organic acids, mainly of tartaric and malic acids, in grapes. These results are likely related to low $\mathrm{pH}$ values in grape must, whose overall $\mathrm{pH}$ in the present study was optimum $(>3.0$ and $<3.8$ ), because numbers above and below the ideal $\mathrm{pH}$ can cause preclude grape must fermentation and change organoleptic features, color, flavor and the oxidation power of wine (Kodur, 2011). Lower SST values in grape must often consist of 95\% sugars (Smart \& Robinson, 1991) and result from the smaller number of clusters per plant - these clusters were noticeably smaller in length and width, which resulted in lower yield (Table 1). Thus, SST tends to be more concentrated in berries from smaller clusters (Guilpart et al., 2014).

Table 2. Composition of grape must from 'Cabernet Sauvignon' grapevines subjected to the application of increasing $\mathrm{K}_{2} \mathrm{O}$ doses in the soil.

\begin{tabular}{|c|c|c|c|c|c|}
\hline \multirow{2}{*}{ Variable } & \multicolumn{3}{|c|}{$\mathrm{K}_{2} \mathrm{O}$ dose $\left(\mathrm{kg} \mathrm{ha}^{-1}\right)$} & \multirow{2}{*}{ Equation } & \multirow{2}{*}{$\mathbf{R}^{2}$} \\
\hline & 0 & 30 & 60 & & \\
\hline & \multicolumn{5}{|c|}{$2011 / 2012$ season } \\
\hline Total Soluble Solids ( ${ }^{\circ}$ Brix) in grape must & 17.3 & 17.2 & 16.7 & - & ns \\
\hline Grape must $\mathrm{pH}$ & 3.18 & 3.22 & 3.19 & - & ns \\
\hline Grape must total titrated acidity (meq $\mathrm{L}^{-1}$ ) & 136.5 & 144.5 & 137.5 & - & ns \\
\hline Grape must tartaric acid (meq L-1) & 1.02 & 1.08 & 1.03 & - & ns \\
\hline Grape must $\mathrm{pH}$ & 3.04 & 3.00 & 3.00 & - & ns \\
\hline Grape must titrated acidity (meq $\mathrm{L}^{-1}$ ) & 198.0 & 205.0 & 211.0 & - & ns \\
\hline \multirow[t]{2}{*}{ Grape must tartaric acid (meq L-1) } & 1.49 & 1.54 & 1.58 & - & ns \\
\hline & \multicolumn{5}{|c|}{$2013 / 2014$ season } \\
\hline Total Soluble Solids ( ${ }^{\circ}$ Brix) in grape must & 19.5 & 19.0 & 19.5 & - & ns \\
\hline
\end{tabular}

ns $=$ not significant $(p \geq 0.05)$. 

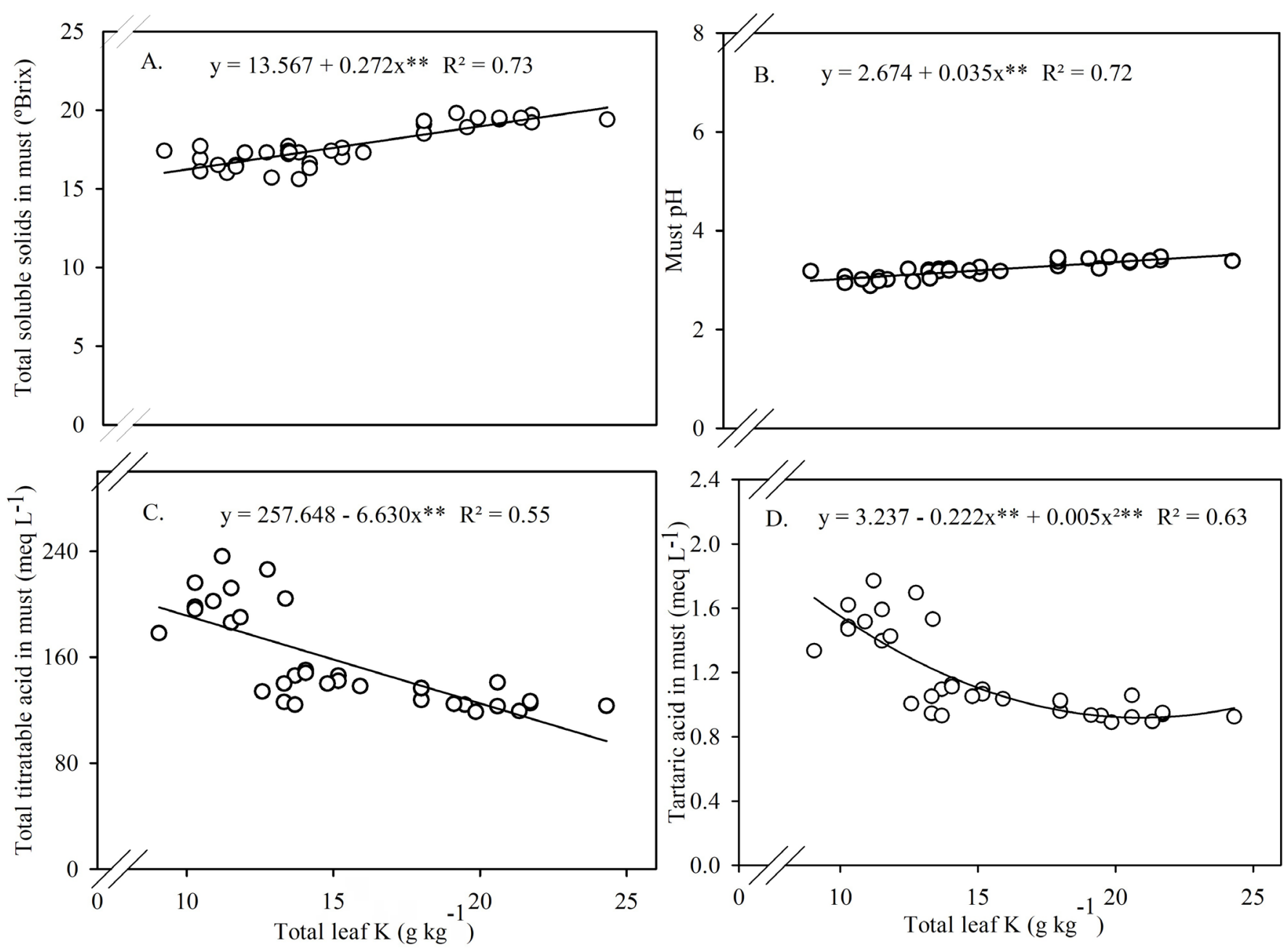

$* *$ significant, $\mathrm{p}<0.01$

Figure 3. Linear regression between total $\mathrm{K}\left(\mathrm{g} \mathrm{kg}^{-1}\right)$ in the leaves at flowering and total soluble solids in grape must ( $\left.{ }^{\circ} \mathrm{Brix}\right)(\mathrm{A})$, grape must $\mathrm{pH}(\mathrm{B})$, total titratable acid in grape must (meq $\left.\mathrm{L}^{-1}\right)(\mathrm{C})$ and Tartaric acid in grape must (meq $\left.\mathrm{L}^{-1}\right)(\mathrm{D})$ from 'Cabernet Sauvignon' subjected to the application of $\mathrm{K}_{2} \mathrm{O}$ doses.

\section{Conclusions}

The application of potassium fertilizers increased $\mathrm{K}$ availability levels in the soil, but only increased $\mathrm{K}$ concentration in leaves collected at full bloom in the $2013 / 2014$ season.

Potassium applications in the soil did not increase grapevine yield but it increased total soluble solids, grape must $\mathrm{pH}$, and decreased total titratable acid and tartaric acid in grape must, which can impair the quality of the wine.

\section{Acknowledgments}

The authors are grateful to Conselho Nacional de Desenvolvimento Científico e Tecnológico (CNPq) for providing productivity grants to them all.

\section{Literature Cited}

Almeida, J.A.; Correa, J.; Schmitt, C. Clay mineralogy of basaltic Hillsides in the Western State of Santa Catarina, Revista Brasileira de Ciência do Solo. v 42, e0170086, 2018. https://doi.org/10.159 0/18069657rbcs20170086.
Boonterm, V.; Silapapun, A.; Boonkerd, N. Effects of nitrogen, potassium fertilizers and clusters per vine on yield and anthocyanin content in Cabernet Sauvignon grape. Acta Horticulture, n. 984, p. 435-442, 2013. https://doi.org/10.17660/ActaHortic.2013.984.54.

Ciotta, M.N.; Ceretta, C.A.; Silva, L.O.E.; Ferreira, P.A.A.; Sautter, C.K.; Couto, R.R.; Brunetto, G. Grape yield, and must compounds of 'Cabernet Sauvignon' grapevine in sandy soil with potassium contents increasing. Ciência Rural, v46, n.8, p.1376-1383, 2016. https://doi.org/10.1590/0103-8478cr20150472.

Comissão de Química e Fertilidade do Solo - CQFS-RS/SC. Manual de calagem e adubação para os estados do Rio Grande do Sul e Santa Catarina. 11.ed. Porto Alegre: SBCS; NRS, 2016. 376 p.

Conde, C.; Silva, P.; Fontes, N.; Dias, A. C.; Tavares, R. M.; Sousa, M. J.; Agasse, A.; Delrot, S.; Gerós, H. Biochemical changes throughout grape berry development and fruit and wine quality. Food, v.1, n.1, p.1-22, 2007. http://citeseerx.ist.psu.edu/viewdoc/downlo ad?doi=10.1.1.553.9177\&rep=rep1\&type=pdf. 29 Jul. 2019.

Dalbo, M.A.; Bettoni, J.C.; Gardin, J.P.P.; Basso, C. Productivity and quality of grapes of cv. Isabel (Vitis labrusca L.) under potassium fertilization. Revista Brasileira de Fruticultura, v.37, n.3, p.789796, 2015. https://doi.org/10.1590/0100-2945-190/14. 
Davies, C.; Shin, R.; Liu, W.; Thomas, M.R.; Schachtman, D.P. Transporters expressed during grape berry (Vitis vinifera $\mathrm{L}$.) development are associated with an increase in berry size and berry potassium accumulation. Journal of Experimental Botany, v.57, n.12, p.32093216, 2006. https://doi.org/10.1093/jxb/erl091.

Dortzbach, D.; Pereira, M.G.; Anjos, L.H.C.; Fontana, A.; Silva Neto, E.C. Genesis and classification of soils from Subtropical Mountain Regions of Southern Brazil. Revista Brasileira de Ciência do Solo, v.40, e0150503, 2016. https://doi.org/10.1590/18069657rb cs20150503.

Empresa de Pesquisa Agropecuária e Extensão Rural de Santa Catarina - Epagri. Agroconnect. Dados Climáticos referentes ao município de Água Doce, 2014. http://www.ciram.sc.gov.br/ agroconnect. 10 Apr. 2019.

Food and Agriculture Organization of the United Nations - FAO; World Soil Information - ISRIC; International Union of Soil Sciences IUSS. World reference base of soil resources. Rome: FAO, 1998. 88p. (FAO. World Soil Resources Reports, 84). http://www.fao. org/soils-portal/resources/world-soil-resources-reports/en. 09 Apr. 2019.

Ganeshamurthy, A.N.; Satisha, G.C.; Patil, P. Potassium nutrition on yield and quality of fruit crops with special emphasis on banana and grapes. Karnataka Journal of Agricultural Sciences, v.24, n.1, p.29-38, 2011. http://14.139.155.167/test5/index.php/kjas/ article/viewFile/4715/4944. 28 Jul. 2019.

Guilpart, N; Metay, A; Gary, C. Grapevine bud fertility and number of berries per bunch are determined by water and nitrogen stress around flowering in the previous year. European Journal of Agronomy, v.54, p.9-20, 2014. https://doi.org/10.1016/j. eja.2013.11.002.

Kodur, S. Effects of juice $\mathrm{pH}$ and potassium on juice and wine quality, and regulation of potassium in grapevines through rootstocks (Vitis): a short review. Vitis Journal of Grapevine Research, v.50, n.1, p. 1-6, 2011. https://doi.org/10.5073/vitis.2011.50.1-6.

Liesche, J. How regulation of phloem transport could link potassium fertilization to increased growth. Tree Physiology, v.36, n.1, p.15, 2016. https://doi.org/10.1093/treephys/tpv120.

Melo, G.W.; Meurer, E.J.; Pinto, L.F.S. Fontes de potássio em solos distroférricos cauliníticos originados de basalto no Rio Grande do Sul. Revista Brasileira de Ciência do Solo, v.28, n.4, p.597-603, 2004. https://doi.org/10.1590/S0100-06832004000400002.

Messiga, AJ.; Gallant, KS.; Sharifi, M.; Hammermeister, A.; Fuller, K.; Tango, $M$,; Fillmore, S.; Grape yield and quality response to cover crops and amendments in a vineyard in Nova Scotia, Canada. American Journal of Enology and Viticulture, v.67, n.1, p.77-85, 2016. https://doi.org/10.5344/ajev.2015.15013.

Oliveira, R.A.D.; Brunetto, G.; Loss, A.; Gatiboni, L.C.; Kürtz, C.; Müller Júnior, V.; Lovato, P.E.; Oliveira, B.S.; Souza, M.; Comin, J.J. Cover crops effects on soil chemical properties and onion yield. Revista Brasileira de Ciência do Solo, v. 40, e0150099, 2016. https://doi. org/10.1590/18069657rbcs20150099.

Pérez-Álvarez, E.P; García-Escudero, E.; Peregrina, F. Soil nutrient availability under cover crops: effects on vines, must, and wine in a Tempranillo vineyard. American Journal of Enology and Viticulture, v. 66, n. 3, p.311-20, 2015. https://doi.org/10.5344/ ajev.2015.14092.
Poonpakdee, C.; Tzeng, J.; Weng, Z.; Lin, Y. Assessment of potassium speciation in soil using traditional single leaching and modified sequential extraction processes. Journal of Soils and Sediments, v.18, n.2, p.610-623, 2018. https://doi.org/10.1007/s11368-017-1773-6.

Pradubsuk, S.; Davenport, J. Season uptake and partitioning of macronutrients an mature 'Concord' grape. Journal of the American Society for Horticultural Science, v.135, n.5, p.474-483, 2010. https://doi.org/10.21273/JASHS.135.5.474.

Rogiers, S.Y.; Coetzee, Z, A.; Walker, R.R.; Deloire, A.; Tyerman, S.D. Potassium in the grape (Vitis vinifera L.) Berry: Transport and Function. Frontiers in Plant Science, v.8, e01629, 2017. https:// doi.org/10.3389/fpls.2017.01629.

Santos, H.G. dos; Jacomine, P.K.T.; Anjos, L.H.C. dos; Oliveira, V.Á. de; Lumbreras, J.F.; Coelho, M.R.; Almeida, J.A. de; Cunha, T.J.F.; Oliveira, J.B. de. Sistema brasileiro de classificação de solos. 3.ed. Brasília: Embrapa, 2013. 353p.

Schmitt, D.E.; Gatiboni, L.C.; Girotto, E.; Lorensini, F.; Melo, G.W.B.; Brunetto, G. Phosphorus fractions in the vineyard soil of the Serra gaúcha of Rio Grande do Sul, Brazil. Revista Brasileira de Engenharia Agrícola e Ambiental, v.18, n.2, p. 134-140, 2014. https://doi.org/10.1590/S1415-43662014000200002.

Sharma, A.; Shankhdhar, D.; Shankhdhar, S.C. Potassium-solubilizing microorganisms: mechanism and their role in potassium solubilization and uptake. In: Meena, V.; Maurya, B.; Verma, J.; Meena, R. (Eds.) Potassium solubilizing microorganisms for sustainable agriculture. New Delhi: Springer, 2016. p.203-219. https://doi.org/10.1007/978-81-322-2776-2_15.

Sipiora, M.J.; Anderson, M.M.; Matthews, M.A. A role of irrigation in managing vine potassium status on a clay soil. In: Soil Environment and Vine Mineral Nutrition Symposium, 2005, San Diego. Proceedings... Davis: American Society for Enology and Viticulture, 2005. p.175-183. http://matthews.ucdavis.edu/ publications-1/Sipiora_Irrigation_revised.pdf. 07 Dec. 2019.

Smart, R; Robinson, M. Sunlight into wine: a handbook for winegrape canopy management. Halifax Street: Winetitles, 1991. 88p.

Soil Survey Staff. Keys to soil taxonomy. 11.ed. Washington: USDA; NRCS, 2010.338p. https://www.nrcs.usda.gov/wps/PA_NRCSConsumption/ download?cid=nrcs142p2_050915\&ext=pdf. 05 Nov. 2019.

Tedesco, M.J.; Gianello, C.; Bissani, C.; Bohnen, H.; Volkweiss, S.J. Análise de solo, plantas e outros materiais. Porto Alegre: UFRGS; Faculdade de Agronomia; 1995. 174p. (UFRGS. Boletim técnico, 5).

Teske, R.; Almeida, J.A.; Hoffer, A.; Lunardi Neto, A. Caracterização mineralógica dos solos derivados de rochas efusivas no Planalto Sul de Santa Catarina, Brasil. Revista de Ciências Agroveterinárias, v12, n.2, p.187-198, 2013. http://revistas.udesc.br/index.php/ agroveterinaria/article/view/5213. 28 Jul. 2019.

Tramontini, S.; Leeuwen, C.V.; Domec, J.; Destrac-Irvine, A.; Basteau, C.; Vitali, M.; Mosbach-Schulz, O.; Lovisolo, C. Impact of texture and water availability on the hydraulic control of plant and grapeberry development. Plant Soil, v.368, n.1-2, p.215-230, 2013. https://doi.org/10.1007/s11104-012-1507-x.

Walker, R.R.; Blackmore, D.H. Potassium concentration and $\mathrm{pH}$ interrelationships in grape juice and wine of Chardonnay and Shirraz from a range of rootstocks in different environments. Australian Journal of Grape and Wine Research, v.18, n.2, p. 183-193, 2012. https://doi.org/10.1111/j.1755-0238.2012.00189.x. 